Article

\title{
Does Corporate Social Responsibility Mediate the Relation between Boardroom Gender Diversity and Firm Performance of Chinese Listed Companies?
}

\author{
Muhammad Safdar Sial ${ }^{1}$, Chunmei Zheng ${ }^{1}$, Jacob Cherian ${ }^{2}{ }^{(1)}$, M.A. Gulzar ${ }^{3}$, \\ Phung Anh Thu ${ }^{4, *}$, Tehmina Khan ${ }^{5}$ and Nguyen Vinh Khuong 6 \\ 1 School of Economics and Management of Wuhan University, Wuhan 430072, China; \\ safdar.sial786@gmail.com (M.S.S.); meiz6523@whu.edu.cn (C.Z.) \\ 2 College of Business, Abu Dhabi University, P.O. Box 59911, Abu Dhabi, UAE; jacob.cherian@adu.ac.ae \\ 3 Waikato Management School, The University of Waikato, Hamilton 3240, New Zealand; \\ awais.gulzar@waikato.ac.nz \\ 4 Faculty of Finance and Accounting, Nguyen Tat Thanh University, Ho Chi Minh City 700000, Vietnam \\ 5 School of Accounting, RMIT University, Melbourne 3000, Australia; tehmina.khan@rmit.edu.au \\ 6 Faculty of Accounting and Auditing, University of Economics and Law, VNU-HCM, \\ Ho Chi Minh City 700000, Vietnam; khuongnv@uel.edu.vn \\ * Correspondence: pathu@ntt.edu.vn; Tel.: +84-772525700
}

Received: 10 September 2018; Accepted: 1 October 2018; Published: 9 October 2018

\begin{abstract}
Although the relationship between board gender diversity and a firm's financial performance has been investigated before, the current study provides a valuable contribution by exploring the complex phenomenon of the mediating impact of corporate social responsibility (CSR) performance on a firm's financial performance. The current study aims to explore whether corporate social responsibility (represented by the proxy variable of CSR reporting) mediates the relationship between boardroom gender diversity and firm performance. We use the pooled ordinary least square (OLS) regression to examine the above relationship by using data from 2008 to 2015. To control the likelihood of endogeneity we also use one-year lagged and two-stage least square (2SLS) regression models. Our results show that boardroom gender diversity is significant, positively correlated with firm performance, and CSR fully mediates the relationship between boardroom gender diversity and firm performance. In addition, four control variables (independent director, Chief executive officer (CEO power), board member meeting frequency, Big4, and leverage) have some influence on firm performance. These findings hold for a set of robustness tests. Our findings have the implication for the investors and regulators. For investors, our results show that the existence of female directors on the board can improve the firm performance. For regulators, our results advise the worldwide policy maker to give the importance to boardroom gender diversity. The paper contributes to the existing studies, by pioneering the investigations of the mediating role of CSR in the relation between boardroom gender diversity and firm performance in Chinese context.
\end{abstract}

Keywords: sustainability; corporate governance; boardroom gender diversity; CSR; firm performance; China; Baron and Kenney's

\section{Introduction}

Corporate social responsibility (CSR) is a broad concept that entails sustainability accounting (social and environmental) as well as sound corporate governance practices. CSR studies are intertwined with numerous disciplines like ecology and society [1]; standard value and ethics [2,3]; institutional monitoring, social, and financial/economic systems [4]; and many other disciplines. 
CSR ideology is used to make the company accountable for the environment and society so that all stakeholders can prosper and companies' negative environmental impacts are reduced [5]. The most widely used approach for companies to use to inform stakeholders about their CSR actions and impacts is through various forms of reporting, for example, through annual reports or other means such as information disclosed on websites, newsletters, and monthly magazines covering these concepts [6]. As a result, we have used global reporting initiative (GRI)-based CSR reporting as a proxy variable for firms' CSR action and impacts. In a large number of countries, there are no laws or disclosure requirements. As such, most of the information is disclosed voluntary; therefore, there has been a growing interest in exploring the reasons/factors that impact companies to report CSR-related information. To be CSR-responsive, companies aim for a beyond-the-profit approach, and they are required to consider all stakeholders and are expected to seriously consider moral values, norms, and principles [7].

Female representation on a company's board has a significant impact on a board's serious consideration of CSR [8]. The more female representation on the company's board, the more enhanced the CSR performance becomes. There is also a positive relationship between board diversity and a firm's overall performance [9]. Gender diversity at a board level is considered an important strategic management of stakeholders' expectations and has become a dominant approach through which companies manage their stakeholders' expectations. The companies that are socially responsible try to make/develop better and sound relationships with stakeholders, for example, with employees, shareholders, and customers ultimately leading to better overall financial performance [10-12].

Even though China's economy is the world's fastest-growing, many companies fail to survive and close down in the initial years. According to Carroll [13] and Friedman [14], in developed markets, CSR is considered to be a duty and a demonstration to stakeholders that the company is a legitimate social entity, whereas in countries like China, which is developing, it is considered as a business tactic and used to gain or maintain market share. Furthermore, it is done for improving the company's brand (image) and is used to increase financial performance and shareholders' wealth.

China is a fast-growing economy and its growth has been occurring at the cost of social and environmental impacts [15,16]. Disclosures and other CSR practices are in the initial stages in China [17]. The big multinational giants and local entities have lowered their labor, environmental, and other standards, and have caused serious damage to the environment. Examples of such negative impacts include those caused by large multinational corporations such as Reebok, Nike, Mattel, and Gap. The lax environmental standards in China have attracted corporations to shift their operations to China [15].

There have been serious breaches of the code of business ethics, a common working style adopted in China. For example, there have been breaches of food safety regulations $[15,18]$, an excessive promotion and use of cigarette and tobacco [19], excessive usage of chemical fertilizers [20], and violations of copyright and trademark laws [21]. The international community has raised serious concerns about these issues.

China has been accused at national and global levels for its approaches towards inadequate environmental, ethical, and trademark issues, as well as other social problems. Experts including accounting professionals, the business community, and academics have suggested that China should have its own environmental and social standards [15] strictly enforced on businesses in China.

Corporate governance laws extensions and reforms have been undertaken in China to cope with international institutional requirements. Multinational entities operating in China are expected to conform to global, environmental, social, and ethical standards [18,22,23]. In the recent past, China has aimed to resolve environmental and social issues of the country, and from 2006, many standards have been made and enforced in true letter and spirit. First, it is required to set up a board of directors for the corporation and limited-liability firms. Second, the number of board of directors should vary from 3 to 13 for a limited liability company and 5 to 19 for a corporation. Third, the governing body also has the duty of recruiting and removing management. Lastly, directors and managers must realistically 
carry out their tasks, protect the organization's interests, and eventually respond to owners. Chinese companies are scrutinized and are required to show that their actions are in accordance with the regulation and standards.

Factors like listing status, ownership structure, and improvements in corporate governance legislation influence the reporting behavior of Chinese companies [24-26]. Accounting bodies and global market pressures compel companies towards CSR reporting homogeneity, where cultural, social, and economic aspects are heterogeneous factors relating to CSR practices. As a result, it is suggested that CSR approaches in China are different from other countries.

Government in China is the key factor for driving CSR [27,28]. China is the second-biggest economy of the world but viewed as a new and transitional economy having distinguishable aspects from those of Anglo-Saxon countries, such as the U.K., USA, and Australia. Most of the corporate governance literature uses the Anglo-Saxon environment and setting while explaining CSR phenomena. Only recently, have studies started to consider economically developing countries' contexts, yet most environmental damages have been occurring in countries like China.

One of the factors that has been studied recently in relation to CSR practices is the impact of female representation at the board level. According to Dutta and Bose [29], there are three justifications for women being on the board. First, women have a better understanding of the market as compared to men; this leads to effective decision-making at the board level [30]. The second justification is that society views the corporations better when there is gender diversity representation at the board level, ultimately leading to a good performance on all matrices [31]. Third, and most importantly, women directors increase the level of understanding of the business environment, hence facilitating better decision-making [32]. Gender diversity is now an important issue for modern organizations [33]. There is increasing pressure internationally for nominating and having more female directors at the top level of management. It is also important to mention that, many countries have undertaken various initiatives, both regulatory and voluntary, to have increased female representation at the board level Vinnicombe [34].

The key aim in this article is to ascertain the impact of gender diversity at the board level from the perspective of female board representation and whether CSR performance has a more dominating impact on firm performance than gender diversity at board level. This is a critical contribution of this research to gender and governance literature. The contribution of this paper is the unique aspect of identifying whether CSR performance (represented by CSR reporting) is more dominating compared to just gender diversity. Two critical questions are addressed in this research. First, does female director's participation at the board level lead to increased firm performance? Second, does CSR mediate the relationship between boardroom gender diversity and firm performance?

Although past literature has considered the impact of gender diversity on Chinese listed companies' financial performance [35-37], our research explores this relationship from a unique angle related to the mediating impact of CSR performance on a firm's financial performance in the presence of gender diversity at the board level. As a survey approach that has been usually adopted in prior literature suffers from non-response and biased sample representation [11,38], an entire population analysis in our research has addressed the weaknesses associated with the survey approach.

We collected the 4257 firm-year observations, representing thirteen industries such as manufacturing, agriculture, electrical power and supplies, mining and dressing, engineering construction, wholesale and retail, information technology, public facilities management, journalism and publication, conglomerate, real estate, transportation, and business services.

Previous studies have not shown how boardroom gender diversity and CSR impacts company performance [39-41] and very few studies have considered the three variables together [36,42,43]. The study of the mediating relationship of CSR between boardroom gender diversity and firm performance has been lacking in past studies. Although our study has looked at the Chinese companies, the results from our study are generalizable from the perspective of the complete mediating impact of CSR reporting (as a proxy for CSR performance) in comparison to just the impact of gender diversity at 
the board level on a firm's financial performance. The remainder of the paper is organized in different sections, which are: Section 2 shows the theory and hypotheses development; Section 3 relates to research design; Section 4 describes the empirical findings; and the last section, Section 5 , provides conclusions with implications for further research.

\section{Theory and Hypotheses Development}

\subsection{Boardroom Gender Diversity and Firm Performance}

Agency theory suggests that female representation on a board usually brings a new point of view to the various problems and eliminates biases relating to information in new strategies development and solving issues [44]. Women officials on a board are also considered to play a more effective role than other members on the board [45].

Female representation has also been found to be linked with higher moral principles at the board level [46] by considering questions regarding unethical behaviors [47]. Gender-diverse boards demonstrate teamwork effectiveness and participative leadership style [48], and addressing of CSR related issues in depth [49], leading towards enhanced performance.

There are mixed results in the literature about boardroom diversity and a firm's performance [50-52]. According to Carter, Simkins [33], there is a positive and significant relationship between the percentage of female directors at the board level and its market performance. Some studies have also shown negative relationship between the female directors at board level and its market performance [53,54], and some have shown no association between the mentioned variables [55-57]. The differences in the results may be due to different research methodologies, statistical tools and techniques, and timeframes selection.

Adler [58] collected a sample of 500 entities and found a strong relationship between board level gender diversity and the firm's financial performance. Carter, Simkins [33] conducted a study using a sample of 638 Fortune ranked companies and found a strong association between board-level diversity and the firm's performance represented by Tobin's $Q$ [59-61]. This relationship has been supported by other studies as well $[31,62,63]$.

Theoretical Underpinnings for Superior Board Performance with Greater Female Representation

According to gender role theory, males and females have the same normally prescribed behaviors, which also concern communications. Females are expected to be assigned more womanly roles, based on the characteristics of gentility and empathy [64]. Whereas male characteristics have been determined as being more aggressive and self-confident compared to females. Furthermore, females are found to be more flexible, leading towards better compatibility and capability, especially in uncertain situations [65]. According to Arfken, Bellar [66] females may have a better understanding of customers, clients, and markets as compared to their male counterparts. We are thus expecting to see a positive relationship between females at the board level and a firm's performance.

According to human capital theory, an individual's characteristics correlate with the board's output, and innovative/creative personnel at senior levels are an asset that leads to increasing the organization's performance [67]. Moreover, both genders have different human capital skills and experiences, hence creating a competitive advantage through diversity [68]. We thus propose the following hypothesis:

Hypothesis 1 (H1). Boardroom gender diversity has a positive effect on firm performance.

\subsection{CSR and Firm Performance}

CSR reporting (as a proxy for a firm's CSR performance) has received significant consideration in the literature and the relationship between CSR performance and a firm's financial performance 
demonstrated through disclosures $[69,70]$ has been tested. Numerous studies have been undertaken worldwide on CSR disclosures and corporate performance; some have shown positive relationships, on the other hand, others have shown negative results, and in many cases, mixed findings have been found. According to Tsoutsoura [71], there is no relationship between a firm's performance and social disclosures. Margolis, Elfenbein [72] examined books, research working papers, research dissertations, and 251 published research papers to find the association between corporate social responsibility and market-based factors of firm performance and found a small positive relationship between CSR and corporate performance.

According to stakeholder theory, not just shareholders but other stakeholders are also impacted by a company's actions. Such stakeholders include the local community, environment, and employees, and thus have to be considered seriously in managers' decisions [73,74]. According to Brown and Forster [75], long term firm performance is affected by relationships with stakeholders and stakeholder management has a critical role to play in the success or failure of a company or organization.

A company's overall performance includes market share, sales growth, and net profit, which has been found to have a positive relationship with the disclosure of corporate social responsibility [76,77]. Slack resources theory was used by Waddock and Graves [78] to describe the significant relationship between CSR practices and performance of the firm, as firms investing slack funds and resources into CSR activities have higher firm performance [78,79]. Julian and Ofori-dankwa [80] found, using slack resources theory, that companies are more inclined to be involved in CSR practices with slack financial resources. This positive association is also found by Surroca, Tribó [81] using a sample of 599 firms from 28 countries.

Chen and Wang [11] studied the relationship between CSR and a firm's performance by utilizing a sample of 141 Chinese companies. They divided CSR disclosures into different categories based on stakeholder needs, for instance, those of employees, society, and customers. They found a positive relationship between CSR performance and a firm's financial performance. Van Beurden and Gössling [82] studied 34 papers on the association between CSR and firm performance and for 23 studies ( 68 per cent) they found the relationship to be positive while 9 studies ( 26 percent) showed no significant relation and only 2 studies (6 per cent) showed an inverse relationship on the CSR-firm performance link. Research on the relation between CSR and firm performance in China is limited. $\mathrm{Zu}$ and Song [83] studied the nature of managers' perceptions toward CSR in China through a questionnaire survey and found a positive relationship between CSR commitment and firm performance. There are very few studies that have directly examined the relationship between CSR and a company's performance in China. The agency problem with Chinese listed companies has been found to be severe as the Chinese government has the most significant ownership. Based on the findings in prior literature, we have developed the following hypothesis.

Hypothesis 2 (H2). There is a positive relation between CSR performance (proxy representation being CSR reporting) and firm performance.

\subsection{Boardroom Gender Diversity and Firm Performance: The Mediation Role of CSR}

Many past studies have supported the positive relationship between female directors at the board level and the firm's performance $[84,85]$. If female directors can influence CSR practices of a firm, then CSR has a positive relationship with the performance of the firm [86,87]. It is considered that firms committed to CSR actions identify and assess the demands of different stakeholders. The result is an increase in efficient corporate governance, leading to adaptation to organizational changes, i.e., a successful change in management process. It has also been found that female directors and CSR, when combined, enhance consideration of stakeholders needs [36]. The CSR can be said to serve as a "filter", facilitating relations between the organization and its board and the environment [88]. These are the basis on which we can say that boardroom gender diversity and a company's performance relationship can be tuned through CSR. 
Hypothesis 3 (H3). CSR mediates the relation between boardroom gender diversity and firm performance.

\section{Research Design}

\subsection{Sample}

We collected the data from Shanghai and Shenzhen stock exchange's listed companies for the period from 2008 to 2015 from the Chinese stock market and accounting research (CSMAR) database. We collected the 4257 firm-year observations, representing industries such as manufacturing, agriculture, electrical power and supplies, mining and dressing, engineering construction, wholesale and retail, information technology, public facilities management, journalism and publication, conglomerate, real estate, transportation, and business services. All variables were winsorized by replacing two values at both extremes.

\subsection{Measures}

We measured the dependent variable, firm performance, by using market-based measures (Tobin Q). We used the Blau index (BI) as a comprehensive measure of boardroom gender diversity [89], which is measured by using this formula $1-\sum_{i=1}^{n} P_{i}^{2}$. The Blau index is a superior measure of boardroom gender diversity as compared to the percentage of female directors as a high percentage of females will indicate more homogeneity in terms of gender on the board [90]. For the mediator variable, we used the CSR reporting index in line with previous studies [63,91,92]; the measurement of the CSR index is shown in Table 1.

Table 1. Corporate social responsibility reporting index.

\begin{tabular}{crc}
\hline & CSR Reporting Items & Binary Scale \\
\hline 1 & Referring to GRI sustainability reporting guideline or not & 1,0 \\
2 & Reporting protection of shareholder interests or not & 1,0 \\
3 & Reporting protection of creditor interests or not & 1,0 \\
4 & Reporting protection of employee interests or not & 1,0 \\
4 & Reporting protection of supplier interests or not & 1,0 \\
6 & Reporting protection of interests of clients and consumers or not & 1,0 \\
7 & Reporting environment and sustainability or not & 1,0 \\
8 & Reporting public relations and social and public welfare or not & 1,0 \\
9 & Reporting social responsibility system construction and improvement or not & 1,0 \\
10 & Reporting secure production or not & 1,0 \\
11 & Reporting deficiencies of company or not & 1,0 \\
\hline The total score of CSR reporting has been computed based on the following formula: $\sum_{n}^{1} \frac{x}{n} \times 100$, where $x$ equals 1 \\
if the item is reported, otherwise 0, and n represent the number of all items.
\end{tabular}

In line with previous studies (Khan and Vieito [63], Abdullah, Mohamed [93], McWilliams and Siegel [94]), and to measure the effect of control variables, we included independent director, CEO power, board member meeting frequency, firm size, leverage, Big4, board size, board member average age, and firm age as control variables. Table 2 provides the list of all variables with their measurements. 
Table 2. Definitions of variables.

\begin{tabular}{|c|c|c|}
\hline Variable Name & Abbreviation & Description \\
\hline $\begin{array}{l}\text { Boardroom gender } \\
\text { diversity }\end{array}$ & BGD & $\begin{array}{l}\text { Boardroom gender diversity is calculated by using the Blau } \\
\text { index, which is measured as } 1-\sum_{i=1}^{n} P_{i}^{2} \text { where } P i \text { is the percent } \\
\text { of male and female in the board and } n \text { is } 2 \text { representing number } \\
\text { of categories (male and female). }\end{array}$ \\
\hline $\begin{array}{l}\text { Proportion of } \\
\text { female director }\end{array}$ & PFD & $\begin{array}{l}\text { Total number of female director divided by total number of } \\
\text { director on the board. }\end{array}$ \\
\hline $\begin{array}{l}\text { Corporate social } \\
\text { responsibility } \\
\text { reporting index }\end{array}$ & CSRRI & $\begin{array}{l}\text { A dichotomous procedure is adopted whereby a company is } \\
\text { awarded } 1 \text { if an item is reported and } 0 \text { if it is not reported, and } \\
\text { the total score of CSR reporting index has been computed based } \\
\text { on the following formula } \sum_{n}^{1} \frac{x}{n} \times 100\end{array}$ \\
\hline Tobin Q & TQ & $\begin{array}{l}\text { (Total assets market capitalization-book value of } \\
\text { equity—deferred tax liability)/total assets. }\end{array}$ \\
\hline $\begin{array}{l}\text { Independent } \\
\text { director }\end{array}$ & ID & $\begin{array}{l}\text { Number of independent directors divided by total directors, } \\
\text { multiplied by } 100 .\end{array}$ \\
\hline CEO power & CEOP & $\begin{array}{l}\text { A dummy variable equal to } 1 \text { if the CEO has the also chair role, } \\
\text { otherwise } 0 .\end{array}$ \\
\hline $\begin{array}{l}\text { Board member } \\
\text { meeting frequency }\end{array}$ & BMMF & Number of board of directors' meetings in a year. \\
\hline Firm size & FS & Natural log of total assets. \\
\hline Leverage & Lev & Total debt divided by total assets. \\
\hline Big4 & Big4 & $\begin{array}{l}\text { A dummy variable that is } 1 \text { if a listed firm is audited by one of } \\
\text { the international Big } 4 \text { audit firms or their joint ventures in } \\
\text { China and zero otherwise. }\end{array}$ \\
\hline Board size & BS & Total number of directors on the board. \\
\hline $\begin{array}{l}\text { Board member } \\
\text { average age }\end{array}$ & BMAA & The average age of board of directors. \\
\hline $\begin{array}{l}\text { State owned } \\
\text { enterprise }\end{array}$ & SOE & $\begin{array}{l}\text { A dummy variable equal to } 1 \text { if the firm is a state-owned } \\
\text { enterprise, otherwise } 0 .\end{array}$ \\
\hline Firm age & FA & Number of year of listing. \\
\hline
\end{tabular}

\subsection{Models Estimation}

We tested the mediation hypothesis of CSR on the relationship between boardroom gender diversity and firm performance. According to Baron and Kenny [95], we used the following pooled regression research model:

$$
\begin{gathered}
\mathrm{TQ}_{\mathrm{it}}=\beta_{0}+\beta_{1} \mathrm{BGD}_{\mathrm{it}}+\sum_{i=1}^{n} \beta_{n} \\
\mathrm{CSR}_{\mathrm{it}}=\beta_{0}+\beta_{1} \mathrm{BGD}_{\mathrm{it}}+\sum_{\mathrm{i}=1}^{\mathrm{n}} \beta_{\mathrm{n}} \\
\mathrm{TQ}_{\mathrm{it}}=\beta_{0}+\beta_{1} \mathrm{BGD}+\beta_{2} \mathrm{CSR}_{\mathrm{it}}+\sum_{i=1}^{n} \beta_{n}
\end{gathered}
$$

According to Baron and Kenny [95], the following conditions must hold to establish mediation: in the first model, TQ is influenced by boardroom gender diversity; in the second model, boardroom gender diversity must affect CSR; and in the third model, when TQ is regressed on both boardroom gender diversity and CSR, CSR must affect TQ. Perfect mediation holds if boardroom gender diversity does not affect TQ in the third model. For a detailed description of variables, see Table 2. 


\section{Empirical Results}

\subsection{Descriptive Statistics}

Table 3 represents the descriptive statistics. The average value of the Blau index is 0.18 , and the mean value of CSR and TQ were 0.73 and 1.80 respectively. The mean value of CEO power was 0.17 , i.e., for $83 \%$ of the companies, the position of $\mathrm{CEO}$ and Chairman are separate. On average, nine boards meetings are held in one year, and $50 \%$ debt exists in Chinese companies. A total of $16 \%$ of Chinese firms have their financial reports audited by the Big 4 , and on average, $60 \%$ of Chinese companies are state-owned enterprises. The descriptive statistics can be found in Table 3.

Table 3. Descriptive Statistics.

\begin{tabular}{cccc}
\hline Variable & Obs & Mean & Std. Dev \\
\hline BGD(BI) & 4257 & 0.1844319 & 0.1590432 \\
CSR & 4257 & 0.7319474 & 0.1480728 \\
TQ & 4257 & 1.808066 & 2.078244 \\
ID & 4257 & 0.3699925 & 0.0662303 \\
CEOP & 4257 & 0.179704 & 0.3839858 \\
BMMF & 4257 & 9.966643 & 4.441063 \\
FS & 4257 & 23.07651 & 1.749106 \\
Lev & 4257 & 0.5098044 & 0.2168527 \\
Big4 & 4257 & 0.1654135 & 0.371597 \\
BS & 4257 & 9.545455 & 2.309339 \\
BMAA & 4257 & 51.27363 & 3.826847 \\
SOE & 4257 & 0.599859 & 0.4899843 \\
FA & 4257 & 11.58388 & 5.634835 \\
\hline
\end{tabular}

\subsection{Correlation Matrix}

Table 4 presents the correlation matrix. The maximum correlation among the variables does not exceed 0.60 . Therefore, no multicollinearity problem can affect the findings. 
Table 4. Pearson correlation.

\begin{tabular}{|c|c|c|c|c|c|c|c|c|c|c|c|c|c|}
\hline & BGD & CSR & $\mathrm{TQ}$ & ID & CEOP & BMMF & FS & Lev & Big4 & BS & BMAA & SOE & FA \\
\hline BGD(BI) & 1.000 & & & & & & & & & & & & \\
\hline CSR & $0.070^{* * *}$ & 1.000 & & & & & & & & & & & \\
\hline TQ & $0.077^{* *}$ & $0.026^{*}$ & 1.000 & & & & & & & & & & \\
\hline ID & $0.027 *$ & 0.000 & 0.025 & 1.000 & & & & & & & & & \\
\hline CEOP & $0.080^{* * *}$ & $0.069 * * *$ & $0.152^{* * *}$ & $0.086^{* * *}$ & 1.000 & & & & & & & & \\
\hline BMMF & $0.050 * * *$ & $0.043^{* * *}$ & $-0.065^{* * *}$ & $0.042^{* * *}$ & -0.012 & 1.000 & & & & & & & \\
\hline FS & $-0.073^{* * *}$ & $0.221^{* * *}$ & $-0.441^{* * *}$ & $0.054^{* *}$ & $-0.132 * * *$ & 0.170 ** & 1.000 & & & & & & \\
\hline Lev & $-0.064^{* * *}$ & $0.131 * *$ & $-0.502^{* * *}$ & 0.017 & $-0.125^{* * *}$ & $0.192 * * *$ & $0.595^{* *}$ & 1.000 & & & & & \\
\hline Big4 & $-0.074 * * *$ & $0.140^{* * *}$ & $-0.170^{* * *}$ & $0.053^{* * *}$ & $-0.079^{* * *}$ & $0.061^{* * *}$ & $0.546^{* *}$ & $0.227^{* * *}$ & 1.000 & & & & \\
\hline BS & $-0.029 * *$ & $0.110^{* * *}$ & $-0.216^{* * *}$ & $-0.246^{* * *}$ & $-0.141^{* * *}$ & 0.023 & $0.445^{* *}$ & $0.257^{* * *}$ & $0.264^{* * *}$ & 1.000 & & & \\
\hline BMAA & $0.098^{* *}$ & $-0.063^{* * *}$ & $-0.110^{* * *}$ & $0.077^{* * *}$ & $-0.065^{* * *}$ & $-0.035 * *$ & $0.201^{* *}$ & $0.073^{* * *}$ & $0.072 * * *$ & $0.062 * * *$ & 1.000 & & \\
\hline SOE & -0.163 * & $0.077^{* * *}$ & $-0.222 * * *$ & $-0.029^{* * *}$ & $-0.230 * *$ & $-0.072 * *$ & $0.291^{* * *}$ & $0.212 * * *$ & $0.167^{* * *}$ & $0.193^{* * *}$ & $0.153^{* * *}$ & 1.000 & \\
\hline FA & $0.033 *$ & $0.095^{* * *}$ & $-0.185^{* * *}$ & -0.014 & $-0.127^{* * *}$ & $0.061^{* * *}$ & $0.189^{* * *}$ & $0.262^{* * *}$ & $0.029^{* *}$ & $0.040^{* * *}$ & $0.205^{* * *}$ & $0.313^{* * *}$ & 1.000 \\
\hline
\end{tabular}

Note: $n=4257,{ }^{* * *},{ }^{* *},{ }^{*}$ represents $p<0.01, p<0.05$, and $p<0.1$, respectively. 


\subsection{Multivariate Analysis}

Table 5 shows the regression results of testing the mediation effect of CSR performance represented by the CSR reporting index on the relation between boardroom gender diversity and firm performance. We applied a three-step regression to test the mediation effect [95]. First, we regressed firm performance on boardroom gender diversity. The coefficient of boardroom gender diversity proxy (BI) in model 1 was positive and significant at the $5 \%$ level $(\beta=0.3406, p<0.05)$, supporting our first hypothesis that boardroom gender diversity has a positive effect on firm performance. This result is consistent with previous studies $[36,59,61]$ and supports gender role theory as female directors are considered to be more flexible, which leads to better capability to manage uncertain situations [65]. Female directors and managers also understand the customers and markets in a better way as compared to males, which leads to improvement in firm performance and human capital as individual characteristics are correlated to its output, and creative individuals are an asset leading to improvements in firm performance [67].

Table 5. Mediation effect of CSR on the relation between boardroom gender diversity and firm performance.

\begin{tabular}{|c|c|c|c|c|c|c|}
\hline \multirow{2}{*}{ Variables } & \multicolumn{2}{|c|}{ Model 1 (TQ) } & \multicolumn{2}{|c|}{ Model 2 (CSR) } & \multicolumn{2}{|c|}{ Model 3 (TQ) } \\
\hline & Coef. & $p$-Value & Coef. & $p$-Value & Coef. & $p$-Value \\
\hline BGD(BI) & $0.3406^{* *}$ & 0.041 & $0.0849^{* * *}$ & 0.000 & 0.2507 & 0.151 \\
\hline CSR & & & & & $1.1510^{* * *}$ & 0.000 \\
\hline ID & $0.9556^{* *}$ & 0.030 & 0.0081 & 0.819 & $0.9628 * *$ & 0.028 \\
\hline CEOP & $0.3279^{* * *}$ & 0.000 & $0.0151^{* *}$ & 0.011 & $0.3465^{* * *}$ & 0.000 \\
\hline BMMF & $0.0151 * *$ & 0.016 & 0.0012 & 0.813 & $0.0151^{* *}$ & 0.016 \\
\hline FS & $-0.2668^{* * *}$ & 0.000 & $0.0157^{* * *}$ & 0.000 & $-0.28481^{* * *}$ & 0.000 \\
\hline Lev & $-3.399^{* * *}$ & 0.000 & -0.0035 & 0.786 & $-3.399^{* * *}$ & 0.000 \\
\hline Big4 & $0.2892^{* * *}$ & 0.001 & $0.0147^{* *}$ & 0.040 & $0.2706^{* * *}$ & 0.002 \\
\hline BS & -0.0066 & 0.631 & 0.00076 & 0.499 & -0.0075 & 0.583 \\
\hline BMAA & -0.0066 & 0.135 & 0.00073 & 0.225 & -0.0121 & 0.104 \\
\hline SOE & $-0.2413^{* * *}$ & 0.000 & 0.0011 & 0.820 & $-0.2418^{* * *}$ & 0.000 \\
\hline FA & $-0.0091 *$ & 0.085 & $0.0012^{* * *}$ & 0.005 & $-0.0104^{* *}$ & 0.049 \\
\hline Constant & $9.9181 * * *$ & 0.000 & $0.8319^{* * *}$ & 0.000 & $8.9619 * * *$ & 0.000 \\
\hline$F$ & \multicolumn{2}{|c|}{160.53} & \multicolumn{2}{|c|}{25.71} & \multicolumn{2}{|c|}{151.50} \\
\hline $\operatorname{Adj}-R^{2}$ & \multicolumn{2}{|c|}{29.67} & \multicolumn{2}{|c|}{6.00} & \multicolumn{2}{|c|}{30.27} \\
\hline
\end{tabular}

Note: $n=4257,{ }^{* * *}, * *,{ }^{*}$ represents $p<0.01, p<0.05$, and $p<0.1$, respectively. For detailed explanation of variables, see Table 2.

In the second step, we regressed CSR on boardroom gender diversity proxy (BI) and the coefficient of the BGD in model 2 was also positive and highly significant at the $1 \%$ level $(\beta=0.0846, p<0.01)$. Finally, in the third step, we regressed firm performance on boardroom gender diversity, as well as CSR together, and the coefficient of CSR was positive and highly significant at the $1 \%$ level $(\beta=1.1510$, $p<0.01)$, supporting the second hypothesis. This finding is in line with previous studies $[11,82]$. This result also supports stakeholder theory as good relationships with stakeholders positively affects long-term corporate performance $[75,76,96]$. Moreover, slack resources theory is also supported as firms with slack financial resources invest in CSR projects to reach a higher standard of corporate performance [78,79]. The reason for this is suggested in organizational theory as follows: with sufficient slack (availability of extra resources to allocate to CSR activities), there can be a solution to every problem such as stakeholder management [97]. Slack acts as a buffer that insulates the technical core of the company from environmental disturbances [96]. It is also a facilitator for companies to undertake strategic behavior such as CSR [98]. When CSR is included in the full model, then the coefficient of boardroom gender diversity proxy (BI) was found to be insignificant in model 3 and the coefficient of CSR was found to be significant at the $1 \%$ level $(\beta=1.1510, p<0.01)$. CSR, as a strategic motive, acts to negate the impact of gender diversity on the firm's financial performance. One reason for this can be the implication that gender diversity is a type of CSR [9]. Thus, companies undertake multiple forms of CSR, including gender diversity at the board level, and allocate slack resources to these efforts to create 
a positive impact on the firm's financial performance. These results are collectively indicating that CSR fully mediates the relation between boardroom gender diversity and firm performance. Hypothesis 3 is also supported.

Moreover, among the control variables, independent director, CEO power, board member meeting frequency, and Big4 were positively related to firm performance and leverage was negatively correlated to firm performance.

\subsection{Robustness Tests}

\subsubsection{Alternative Measure of Boardroom Gender Diversity}

To ensure the robustness of our findings, we used the proportion of female director (PFD) as an alternative measure of boardroom gender diversity $[44,99,100]$ by dividing the female directorship (number of female directors) by the total number of directors serving on each company in the boardroom. The coefficient of PFD was positive and significant in model 1 ( $\beta=0.4438, p<0.05)$ and model $2(\beta=0.0935, p<0.01)$, and insignificant in model 3. The coefficient of CSR in model 3 was significant at the $1 \%$ level $(\beta=1.1517, p<0.01)$, indicating that CSR fully mediates the relationship between boardroom gender diversity and firm performance. The results of Table 6 were also consistent with our main findings.

Table 6. Does firm performance mediate the relation between board gender diversity and CSR reporting?

\begin{tabular}{|c|c|c|c|c|c|c|}
\hline \multirow{2}{*}{ Variables } & \multicolumn{2}{|c|}{ Model 1 (TQ) } & \multicolumn{2}{|c|}{ Model 2 (CSR) } & \multicolumn{2}{|c|}{ Model 3 (TQ) } \\
\hline & Coef. & $p$-Value & Coef. & $p$-Value & Coef. & $p$-Value \\
\hline PFD & $0.4438^{* *}$ & 0.042 & $0.0935^{* * *}$ & 0.000 & 0.3457 & 0.112 \\
\hline CSR & & & & & $1.1517^{* * *}$ & 0.000 \\
\hline ID & $0.9448^{* *}$ & 0.031 & 0.0108 & 0.760 & $0.9549 * *$ & 0.029 \\
\hline CEOP & $0.3281^{* * *}$ & 0.000 & $0.0149^{* *}$ & 0.012 & $0.3464^{* * *}$ & 0.000 \\
\hline BMMF & $0.01524^{* *}$ & 0.015 & 0.00015 & 0.770 & $0.0151^{* *}$ & 0.016 \\
\hline FS & $-0.2669^{* * *}$ & 0.000 & $0.0157^{* * *}$ & 0.000 & $-0.2850^{* * *}$ & 0.000 \\
\hline Lev & $-3.3998^{* * *}$ & 0.000 & -0.0041 & 0.750 & $-3.3992^{* * *}$ & 0.000 \\
\hline Big4 & $0.2881^{* * *}$ & 0.001 & $0.0143^{* *}$ & 0.047 & $0.2700^{* * *}$ & 0.002 \\
\hline BS & -0.0055 & 0.687 & 0.0010 & 0.373 & -0.0067 & 0.625 \\
\hline BMAA & -0.0109 & 0.143 & 0.00073 & 0.229 & -0.01190 & 0.111 \\
\hline SOE & $-0.2385^{* * *}$ & 0.000 & 0.0010 & 0.838 & $-0.2389^{* * *}$ & 0.000 \\
\hline FA & $-0.0094 *$ & 0.076 & $0.0011^{* * *}$ & 0.006 & $-0.0107^{* *}$ & 0.044 \\
\hline Constant & $9.9145^{* * *}$ & 0.000 & $0.8358^{* * *}$ & 0.000 & $8.9537^{* * *}$ & 0.000 \\
\hline$F$ & \multicolumn{2}{|c|}{160.58} & \multicolumn{2}{|c|}{24.96} & \multicolumn{2}{|c|}{151.56} \\
\hline Adj- $R^{2}$ & \multicolumn{2}{|c|}{29.67} & \multicolumn{2}{|c|}{5.83} & \multicolumn{2}{|c|}{30.28} \\
\hline
\end{tabular}

Note: $n=4257,{ }^{* * *},{ }^{* *},{ }^{*}$ represents $p<0.01, p<0.05, p<0.1$. For detail explanation of variables see Table 2 .

\subsubsection{Problem of Endogeneity}

In Table 7, to control the possible problem of endogeneity, we used alternative models. First, we used the one-year lagged values of boardroom gender diversity proxy because women directors need some time to affect the decision-making of the board. The coefficient of the Blau index (BI) was significant in model $1(\beta=0.074, p<0.1)$ and model $2(\beta=0.070, p<0.01)$, and insignificant in model 3 . Moreover, the coefficient of CSR was highly significant in model $3(\beta=1.173, p<0.01)$, which confirms our main results. Second, we used a two-stage least square (TSLS) method [101] by considering the lag value of the Blau index (BI) as an instrument variable that likely meets the requirement that it is not correlated with the firm performance but related with the decision of female directorship in the boardroom. The coefficient of the Blau index (BI) was significant in model 4 at the $10 \%$ level $(\beta=0.119$, $p<0.1)$, in model 5 , it was significant at the $1 \%$ level $(\beta=0.112, p<0.1)$, and insignificant in model 6 . Moreover, the coefficient of CSR was highly significant in model 6 at the $1 \%$ level $(\beta=1.173, p<0.01)$, which was consistent with our main findings (see Figure 1). 
Table 7. Does firm performance mediate the relation between board gender diversity and CSR reporting?

\begin{tabular}{|c|c|c|c|c|c|c|c|c|c|c|c|c|}
\hline \multirow{3}{*}{ Variables } & \multicolumn{6}{|c|}{ Lag of Independent Variables } & \multicolumn{6}{|c|}{ Two-Stage Least Square (2SLS) } \\
\hline & \multicolumn{2}{|c|}{ Model 1 (TQ) } & \multicolumn{2}{|c|}{ Model 2 (CSR) } & \multicolumn{2}{|c|}{ Model 3 (TQ) } & \multicolumn{2}{|c|}{ Model 4 (TQ) } & \multicolumn{2}{|c|}{ Model 5 (CSR) } & \multicolumn{2}{|c|}{ Model 6 (TQ) } \\
\hline & Coef. & $p$-Value & Coef. & $p$-Value & Coef. & $p$-Value & Coef. & $p$-Value & Coef. & $p$-Value & Coef & $p$-Value \\
\hline BGD(BI) & 0.074 * & 0.066 & $0.070^{* * *}$ & 0.000 & 0.0055 & 0.974 & 0.119 * & 0.066 & $0.112 * * *$ & 0.000 & 0.008 & 0.974 \\
\hline CSR & & & & & $1.173^{* * *}$ & 0.000 & & & & & $1.173^{* * *}$ & 0.000 \\
\hline ID & $0.947^{* *}$ & 0.031 & 0.012 & 0.728 & $0.958^{* *}$ & 0.029 & $0.952^{* *}$ & 0.030 & 0.006 & 0.864 & $0.957^{* *}$ & 0.028 \\
\hline CEOP & $0.333^{* * *}$ & 0.000 & $0.014^{* *}$ & 0.015 & $0.352 * * *$ & 0.000 & $0.332^{* * *}$ & 0.000 & $0.015^{* * *}$ & 0.008 & $0.352^{* * *}$ & 0.000 \\
\hline BMMF & $0.015^{*}$ & 0.013 & -0.002 & 0.666 & $0.0154^{* *}$ & 0.013 & $0.015^{* *}$ & 0.013 & 0.008 & 0.869 & $0.015^{* *}$ & 0.013 \\
\hline FS & $-0.265^{* * *}$ & 0.000 & $-0.016^{* * *}$ & 0.000 & $-0.284^{* * *}$ & 0.000 & $-0.266^{* * *}$ & 0.000 & $0.015^{* * *}$ & 0.000 & $-0.284^{* * *}$ & 0.000 \\
\hline Lev & $-3.41^{* * *}$ & 0.000 & 0.005 & 0.663 & $-3.41^{* * *}$ & 0.000 & $-3.41^{* * *}$ & 0.000 & -0.002 & 0.852 & $-3.413^{* * *}$ & 0.000 \\
\hline Big4 & $0.282^{* * *}$ & 0.001 & $-0.014^{* *}$ & 0.051 & $0.264^{* * *}$ & 0.003 & $0.283^{* * *}$ & 0.001 & $0.015^{* *}$ & 0.035 & $0.264^{* *}$ & 0.003 \\
\hline BS & -0.006 & 0.642 & -0.0006 & 0.566 & -0.007 & 0.600 & -0.006 & 0.644 & 0.0007 & 0.529 & -0.007 & 0.599 \\
\hline BMAA & -0.012 & 0.103 & -0.0006 & 0.264 & -0.013 * & 0.078 & -0.012 & 0.110 & 0.0008 & 0.167 & -0.013 * & 0.080 \\
\hline $\mathrm{SOE}$ & $-0.256^{* * *}$ & 0.000 & 0.0005 & 0.917 & $-0.255^{* * *}$ & 0.000 & $-0.252^{* * *}$ & 0.000 & 0.002 & 0.610 & $-0.255^{* * *}$ & 0.000 \\
\hline FA & -0.008 & 0.123 & $-0.001^{* * *}$ & 0.002 & $-0.009 *$ & 0.068 & -0.008 & 0.115 & $0.001^{* *}$ & 0.011 & $-0.009^{* *}$ & 0.072 \\
\hline Constant & $10.0^{* * *}$ & 0.000 & $0.8358^{* * *}$ & 0.000 & $9.02^{* * *}$ & 0.000 & $9.98^{* * *}$ & 0.000 & $0.822^{* * *}$ & 0.000 & $9.026^{* * *}$ & 0.000 \\
\hline$F$ & \multicolumn{2}{|c|}{159.97} & \multicolumn{4}{|c|}{151.16} & \multirow{2}{*}{\multicolumn{2}{|c|}{1765.66}} & \multirow{2}{*}{\multicolumn{2}{|c|}{270.83}} & \multirow{2}{*}{\multicolumn{2}{|c|}{181951}} \\
\hline WaldChi2 & \multirow{2}{*}{\multicolumn{2}{|c|}{29.60}} & \multirow{2}{*}{\multicolumn{2}{|c|}{5.73}} & & & & & & & & \\
\hline Adj- $R^{2}$ & & & & & \multicolumn{2}{|c|}{30.23} & \multicolumn{2}{|c|}{29.82} & \multicolumn{2}{|c|}{6.13} & \multicolumn{2}{|c|}{30.43} \\
\hline
\end{tabular}




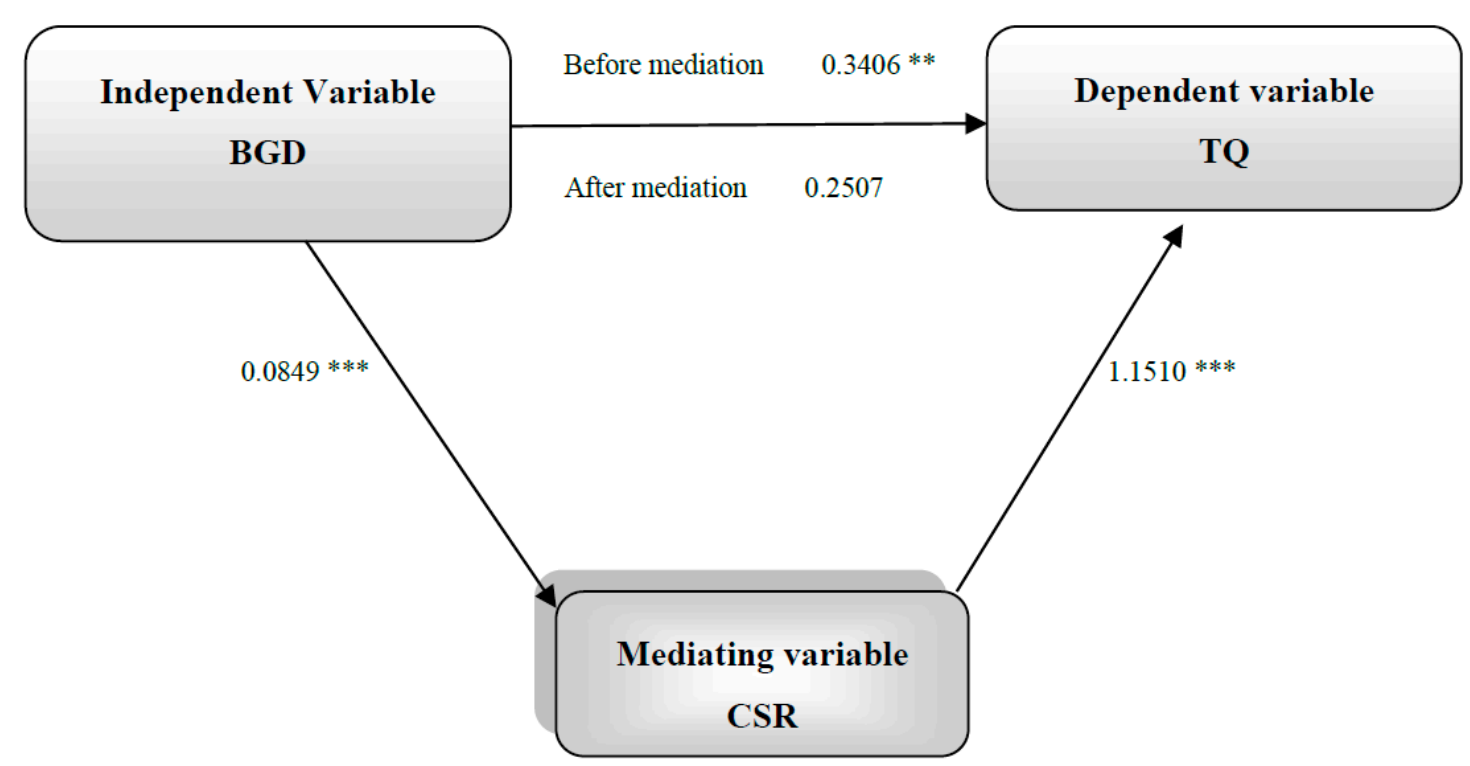

Figure 1. Mediation of CSR on board gender diversity and firm performance. Note: ${ }^{* *}$ and ${ }^{* *}$ represents $p<0.01$ and $p<0.05$.

\section{Conclusions and Future Research}

The current study investigated the impact of boardroom gender diversity on firm performance and extends the mediating role of CSR on the relationship between boardroom gender diversity and firm performance by using 4257 firm-year observations ranging from 2008 to 2015. Our findings show that boardroom gender diversity had a significant impact on firm performance. Second, besides establishing the direct link between boardroom gender diversity and firm performance, we have contributed to the boardroom gender diversity literature by theoretically proposing and empirically showing that CSR completely mediates the effects of boardroom gender diversity on firm performance. We found that CSR fully mediates the boardroom gender diversity-firm performance link. Therefore, this study responds to calls to examine the underlying mechanisms of boardroom gender diversity $[102,103]$ and fills an important research gap.

In other words, the implications from this study suggest that board gender diversity has a positive impact on firm performance, yet the reason or cause for board gender diversity could be to enhance CSR performance as CSR performance has a positive and significant impact on firm performance. In other words, the key implication of our research is that boardroom gender diversity is one of the features of a firm's CSR activities and that as one of the many elements of CSR activities Weber [104], it had a positive impact on firm performance. Yet, when CSR performance was considered through the de facto representation by CSR reporting $[105,106]$, it takes over as an impact on a firm's performance, being a strategic resource slack measure by a firm. This implication also supports the theoretical idea of addressing various stakeholder needs including, but not limited to, the increasing demand for gender diversity on the board [44]. There are other CSR performance measures (as represented by the CSR reporting index) that have proven to be dominant in their impact on firm performance in comparison to the sole impact of board gender diversity.

The direct effect of boardroom gender diversity on firm performance was not established due to other mediator and moderator variables that play an important role in the relationship between boardroom gender diversity and firm performance. Although we have taken CSR as a mediator variable, several other variables exist that will mediate or moderate this relationship (e.g., state ownership, firm performance, and institutional investors). Future studies are required to investigate other possible CSR variables that could impact firm performance in various contexts, including in developing country contexts. Future research should be able to divide the CSR disclosures into 
sub-categories to investigate the detailed relationship between boardroom gender diversity and each category of CSR and firm performance.

Author Contributions: M.S.S.: Conceptualization, Formal analysis, Investigation, Methodology, Writing —original draft and Writing—review \& editing; C.Z.: Conceptualization, Writing-review \& editing, Supervision; J.C.: Conceptualization, Methodology, Writing—review \& editing; M.A.G.: Conceptualization, Writing—review \& editing; P.A.T.: Conceptualization, Methodology, Formal analysis, Writing-original draft, Writing-review \& editing; T.K.: Conceptualization, Writing—review \& editing; N.V.K.: Conceptualization, Writing—review \& editing.

Conflicts of Interest: The authors declare no conflict of interest.

\section{References}

1. Parker, J. Integrating CSR with hospitality management programmes in higher education. Int. J. Green Econ. 2011, 5, 396-404. [CrossRef]

2. Abeysuriya, K.; Mitchell, C.; White, S. Can corporate social responsibility resolve the sanitation question in developing Asian countries? Ecol. Econ. 2007, 62, 174-183. [CrossRef]

3. Teck Hui, L. Combining faith and CSR: A paradigm of corporate sustainability. Int. J. Soc. Econ. 2008, 35, 449-465. [CrossRef]

4. Ball, A.; Craig, R. Using neo-institutionalism to advance social and environmental accounting. Crit. Perspect. Account. 2010, 21, 283-293. [CrossRef]

5. Newell, P. Citizenship, accountability and community: The limits of the CSR agenda. Int. Aff. 2005, 81, 541-557. [CrossRef]

6. Golob, U.; Bartlett, J.L. Communicating about corporate social responsibility: A comparative study of CSR reporting in Australia and Slovenia. Public Relat. Rev. 2007, 33, 1-9. [CrossRef]

7. Lafuente, A.; Viñuales, V.; Pueyo, R.; Llaría, J. Responsabilidad Social Corporativas Y Politicas Publicas; Fundacion Alternativas: Madrid, Spain, 2003.

8. Bear, S.; Rahman, N.; Post, C. The impact of board diversity and gender composition on corporate social responsibility and firm reputation. J. Bus. Ethics 2010, 97, 207-221. [CrossRef]

9. Rao, K.; Tilt, C. Board composition and corporate social responsibility: The role of diversity, gender, strategy and decision making. J. Bus. Ethics 2016, 138, 327-347. [CrossRef]

10. Davis, K. The case for and against business assumption of social responsibilities. Acad. Manag. J. 1973, 16, 312-322.

11. Chen, H.; Wang, X. Corporate social responsibility and corporate financial performance in China: An empirical research from Chinese firms. Corp. Gov. Int. J. Bus. Soc. 2011, 11, 361-370. [CrossRef]

12. Turban, D.B.; Greening, D.W. Corporate social performance and organizational attractiveness to prospective employees. Acad. Manag. J. 1997, 40, 658-672.

13. Carroll, A.B. A three-dimensional conceptual model of corporate performance. Acad. Manag. Rev. 1979, 4, 497-505. [CrossRef]

14. Friedman, M. The Social Responsibility of Business Is to Increase Its Profits. New Cork Times Magazine, 13 September 1970.

15. Tang, L.; Li, H. Corporate social responsibility communication of Chinese and global corporations in China. Public Relat. Rev. 2009, 35, 199-212. [CrossRef]

16. Lin, C.-Y.; Ho, Y.-H. Determinants of green practice adoption for logistics companies in China. J. Bus. Ethics 2011, 98, 67-83. [CrossRef]

17. Noronha, C.; Tou, S.; Cynthia, M.I.; Guan, J.J. Corporate social responsibility reporting in China: An overview and comparison with major trends. Corp. Soc. Resp. Environ. Manag. 2013, 20, 29-42. [CrossRef]

18. Zhou, $C$. The future roles of STPs in green growth of China: Based on the public-university-industry triple helix for sustainable development. J. Knowl.-Based Innov. China 2011, 3, 216-229. [CrossRef]

19. Cai, H.; Wang, X. The substitution effect of cigarette excise tax for tobacco leaf tax in China. China Agric. Econ. Rev. 2010, 2, 385-395. [CrossRef]

20. Wu, Y. Chemical fertilizer use efficiency and its determinants in China's farming sector: Implications for environmental protection. China Agric. Econ. Rev. 2011, 3, 117-130. [CrossRef] 
21. Tian, D.; Chao, C.-C. Strategies under pressure: USA-China copyright dispute. J. Sci. Technol. Policy China 2011, 2, 219-237. [CrossRef]

22. Fang, X. Re-examining the reform of China's science and technology system: A historical perspective. J. Sci. Technol. Policy China 2010, 1, 7-17. [CrossRef]

23. Hongwei, W.; Ping, L. Empirical analysis of the sources of China's economic growth in 1978-2008. J. Knowl.-Based Innov. China 2011, 3, 91-105. [CrossRef]

24. Cheung, Y.-L.; Jiang, P.; Tan, W. A transparency disclosure index measuring disclosures: Chinese listed companies. J. Account. Public Policy 2010, 29, 259-280. [CrossRef]

25. Wang, K.; Sewon, O.; Claiborne, M.C. Determinants and consequences of voluntary disclosure in an emerging market: Evidence from China. J. Int. Account. Audit. Tax. 2008, 17, 14-30. [CrossRef]

26. Xiao, H.; Yuan, J. Ownership structure, board composition and corporate voluntary disclosure: Evidence from listed companies in China. Manag. Audit. J. 2007, 22, 604-619.

27. Tang, Z.; Tang, J. Stakeholder-firm power difference, stakeholders' CSR orientation, and SMEs' environmental performance in China. J. Bus. Ventur. 2012, 27, 436-455. [CrossRef]

28. Guo, J.; Sun, L.; Li, X. Corporate social responsibility assessment of Chinese corporations. Int. J. Bus. Manag. 2009, 4, 54. [CrossRef]

29. Dutta, P.; Bose, S. Gender Diversity in the Boardroom and Financial Performance of Commercial Banks: Evidence from Bangladesh. Available online: https://core.ac.uk/download/pdf/12015783.pdf (accessed on 9 October 2018).

30. Erhardt, N.L.; Werbel, J.D.; Shrader, C.B. Board of director diversity and firm financial performance. Corp. Gov. Int. Rev. 2003, 11, 102-111. [CrossRef]

31. Dezsö, C.L.; Ross, D.G. Does female representation in top management improve firm performance? A panel data investigation. Strateg. Manag. J. 2012, 33, 1072-1089. [CrossRef]

32. Smith, N.; Smith, V.; Verner, M. Do women in top management affect firm performance? A panel study of 2500 Danish firms. Int. J. Product. Perform. Manag. 2006, 55, 569-593. [CrossRef]

33. Carter, D.A.; Simkins, B.J.; Simpson, W.G. Corporate governance, board diversity, and firm value. Financ. Rev. 2003, 38, 33-53. [CrossRef]

34. Vinnicombe, S. Women on Corporate Boards of Directors: International Research and Practice; Edward Elgar Publishing: Cheltenham, UK, 2009.

35. Clacher, I.; Hagendorff, J. Do announcements about corporate social responsibility create or destroy shareholder wealth? Evidence from the UK. J. Bus. Ethics 2012, 106, 253-266. [CrossRef]

36. Jo, H.; Harjoto, M.A. Corporate governance and firm value: The impact of corporate social responsibility. J. Bus. Ethics 2011, 103, 351-383. [CrossRef]

37. Muller, A.; Kolk, A. Extrinsic and intrinsic drivers of corporate social performance: Evidence from foreign and domestic firms in Mexico. J. Manag. Stud. 2010, 47, 1-26. [CrossRef]

38. Qu, W.; Leung, P. Cultural impact on Chinese corporate disclosure-A corporate governance perspective. Manag. Audit. J. 2006, 21, 241-264. [CrossRef]

39. Walls, J.L.; Berrone, P.; Phan, P.H. Corporate governance and environmental performance: Is there really a link? Strateg. Manag. J. 2012, 33, 885-913. [CrossRef]

40. Hung, H. Directors' roles in corporate social responsibility: A stakeholder perspective. J. Bus. Ethics 2011, 103, 385-402. [CrossRef]

41. De Villiers, C.; Naiker, V.; Van Staden, C.J. The effect of board characteristics on firm environmental performance. J. Manag. 2011, 37, 1636-1663. [CrossRef]

42. Sahin, K.; Basfirinci, C.S.; Ozsalih, A. The impact of board composition on corporate financial and social responsibility performance: Evidence from public-listed companies in Turkey. Afr. J. Bus. Manag. 2011, 5, 2959-2978.

43. Arora, P.; Dharwadkar, R. Corporate governance and corporate social responsibility (CSR): The moderating roles of attainment discrepancy and organization slack. Corp. Gov. Int. Rev. 2011, 19, 136-152. [CrossRef]

44. Francoeur, C.; Labelle, R.; Sinclair-Desgagné, B. Gender diversity in corporate governance and top management. J. Bus. Ethics 2008, 81, 83-95. [CrossRef]

45. Virtanen, A. Women on the boards of listed companies: Evidence from Finland. J. Manag. Gov. 2012, 16, 571-593. [CrossRef] 
46. Pan, Y.; Sparks, J.R. Predictors, consequence, and measurement of ethical judgments: Review and meta-analysis. J. Bus. Res. 2012, 65, 84-91. [CrossRef]

47. Bilimoria, D.; Wheeler, J.V. Women corporate directors: Current research and future directions. Women Manag. Curr. Res. Issues 2000, 2, 138-163.

48. Eagly, A.H.; Johnson, B.T. Gender and leadership style: A meta-analysis. Psychol. Bull. 1990, 108, $233-256$. [CrossRef]

49. Ingley, C.; Van Der Walt, N. Do board processes influence director and board performance? Statutory and performance implications. Corp. Gov. Int. Rev. 2005, 13, 632-653. [CrossRef]

50. Post, C.; Byron, K. Women on boards and firm financial performance: A meta-analysis. Acad. Manag. J. 2015, 58, 1546-1571. [CrossRef]

51. Ferreira, D. Board diversity: Should we trust research to inform policy? Corp. Gov. Int. Rev. 2015, 23, $108-111$. [CrossRef]

52. Larcker, D.; Tayan, B. Corporate Governance Matters: A Closer Look at Organizational Choices and Their Consequences; Pearson Education: London, UK, 2015.

53. Matsa, D.A.; Miller, A.R. A female style in corporate leadership? Evidence from quotas. Am. Econ. J. Appl. Econ. 2013, 5, 136-169. [CrossRef]

54. Ahern, K.R.; Dittmar, A.K. The changing of the boards: The impact on firm valuation of mandated female board representation. Q. J. Econ. 2012, 127, 137-197. [CrossRef]

55. Adams, R.B.; Ferreira, D. Women in the boardroom and their impact on governance and performance. J. Financ. Econ. 2009, 94, 291-309. [CrossRef]

56. Jurkus, A.F.; Park, J.C.; Woodard, L.S. Women in top management and agency costs. J. Bus. Res. 2011, 64, 180-186. [CrossRef]

57. Carter, D.A.; D'Souza, F.; Simkins, B.J.; Simpson, W.G. The gender and ethnic diversity of US boards and board committees and firm financial performance. Corp. Gov. Int. Rev. 2010, 18, 396-414. [CrossRef]

58. Adler, R.D. Women in the executive suite correlate to high profits. Harv. Bus. Rev. 2001, 79, $30-32$.

59. Huang, S.K. The impact of CEO characteristics on corporate sustainable development. Corp. Soc. Responsib. Environ. Manag. 2013, 20, 234-244.

60. Harjoto, M.; Laksmana, I.; Lee, R. Board diversity and corporate social responsibility. J. Bus. Ethics 2015, 132, 641-660. [CrossRef]

61. Gupta, P.P.; Lam, K.C.; Sami, H.; Zhou, H. Board Diversity and Its Long-Term Effect on Firm Financial and Non-Financial Performance. Available online: https:/ / papers.ssrn.com/sol3/papers.cfm?abstract_id= 2531212 (accessed on 9 October 2018).

62. Terjesen, S.; Couto, E.B.; Francisco, P.M. Does the presence of independent and female directors impact firm performance? A multi-country study of board diversity. J. Manag. Gov. 2016, 20, 447-483. [CrossRef]

63. Khan, W.A.; Vieito, J.P. CEO gender and firm performance. J. Econ. Bus. 2013, 67, 55-66.

64. Eagly, A.H. Sex Differences in Social Behavior: A Social-Role Interpretation, Lawrance Erlbaum Associates; Lawrence Erlbaum: Hillsdale, NJ, USA, 1987.

65. Rosener, J. America's Competitive Secret: Utilizing Women as A Power Strategy; Oxford University Press: New York, NY, USA, 1995.

66. Arfken, D.E.; Bellar, S.L.; Helms, M.M. The ultimate glass ceiling revisited: The presence of women on corporate boards. J. Bus. Ethics 2004, 50, 177-186. [CrossRef]

67. Becker, G.S. Human Capital: A Theoretical and Empirical Analysis, with Special Reference to Education; National Bureau of Economic Research: New York, NY, USA, 1964.

68. Singh, V.; Terjesen, S.; Vinnicombe, S. Newly appointed directors in the boardroom: How do women and men differ? Eur. Manag. J. 2008, 26, 48-58. [CrossRef]

69. Margolis, J.D.; Elfenbein, H.A.; Walsh, J.P. Does it Pay to be Good? A Meta-Analysis and Redirection of Research on the Relationship between Corporate Social Responsibility and Financial Performance; Working Paper; University of Michigan: Ann Arbor, MI, USA, 2007.

70. Orlitzky, M.; Schmidt, F.L.; Rynes, S.L. Corporate social and financial performance: A meta-analysis. Organ. Stud. 2003, 24, 403-441. [CrossRef]

71. Tsoutsoura, M. Corporate Social Responsibility and Financial Performance. Available online: https:// escholarship.org/uc/item/111799p2 (accessed on 9 October 2018). 
72. Margolis, J.D.; Elfenbein, H.A.; Walsh, J.P. Does it Pay to be Good ... and Does it Matter? A Meta-Analysis of the Relationship between Corporate Social and Financial Performance. Available online: https:/ / papers. ssrn.com/sol3/papers.cfm?abstract_id=1866371 (accessed on 9 October 2018).

73. Castelo Branco, M.; Lima Rodriques, L. Positioning stakeholder theory within the debate on corporate social responsibility. EJBO-Electron. J. Bus. Ethics Organ. Stud. 2007, 12, 5-15.

74. Freeman, R.E. Strategic Management: A Stakeholder Approach; Cambridge University Press: Cambridge, UK, 2010.

75. Brown, J.A.; Forster, W.R. CSR and stakeholder theory: A tale of Adam Smith. J. Bus. Ethics 2013, 112, 301-312. [CrossRef]

76. Barnett, M.L.; Salomon, R.M. Does it pay to be really good? Addressing the shape of the relationship between social and financial performance. Strateg. Manag. J. 2012, 33, 1304-1320. [CrossRef]

77. Menguc, B.; Ozanne, L.K. Challenges of the "green imperative": A natural resource-based approach to the environmental orientation-business performance relationship. J. Bus. Res. 2005, 58, 430-438. [CrossRef]

78. Waddock, S.A.; Graves, S.B. The corporate social performance-financial performance link. Strateg. Manag. J. 1997, 303-319. [CrossRef]

79. McGuire, J.B.; Sundgren, A.; Schneeweis, T. Corporate social responsibility and firm financial performance. Acad. Manag. J. 1988, 31, 854-872.

80. Julian, S.D.; Ofori-dankwa, J.C. Financial resource availability and corporate social responsibility expenditures in a sub-Saharan economy: The institutional difference hypothesis. Strateg. Manag. J. 2013, 34, 1314-1330. [CrossRef]

81. Surroca, J.; Tribó, J.A.; Waddock, S. Corporate responsibility and financial performance: The role of intangible resources. Strateg. Manag. J. 2010, 31, 463-490. [CrossRef]

82. Van Beurden, P.; Gössling, T. The worth of values-A literature review on the relation between corporate social and financial performance. J. Bus. Ethics 2008, 82, 407-424. [CrossRef]

83. Zu, L.; Song, L. Determinants of managerial values on corporate social responsibility: Evidence from China. J. Bus. Ethics 2009, 88, 105-117. [CrossRef]

84. Bebchuk, L.A.; Weisbach, M.S. The state of corporate governance research. Rev. Financ. Stud. 2010, 23, 939-961. [CrossRef]

85. Chhaochharia, V.; Grinstein, Y. CEO compensation and board structure. J. Financ. 2009, 64, $231-261$. [CrossRef]

86. Carroll, A.B.; Shabana, K.M. The business case for corporate social responsibility: A review of concepts, research and practice. Int. J. Manag. Rev. 2010, 12, 85-105. [CrossRef]

87. Kurucz, E.C.; Colbert, B.A.; Wheeler, D. The business case for corporate social responsibility. In The Oxford Handbook of Corporate Social Responsibility; Oxford University Press: Oxford, UK, 2008.

88. Fassin, Y.; Van Rossem, A. Corporate governance in the debate on CSR and ethics: Sensemaking of social issues in management by authorities and CEOs. Corp. Gov. Int. Rev. 2009, 17, 573-593. [CrossRef]

89. Blau, P.M. Inequality and Heterogeneity: A Primitive Theory of Social Structure; Free Press: New York, NY, USA, 1977; Volume 7.

90. Campbell, K.; Mínguez-Vera, A. Gender diversity in the boardroom and firm financial performance. J. Bus. Ethics 2008, 83, 435-451. [CrossRef]

91. Ahmed Haji, A. Corporate social responsibility disclosures over time: Evidence from Malaysia. Manag. Audit. J. 2013, 28, 647-676. [CrossRef]

92. Haniffa, R.M.; Cooke, T.E. The impact of culture and governance on corporate social reporting. J. Account. Public Policy 2005, 24, 391-430. [CrossRef]

93. Abdullah, S.N.; Mohamed, N.R.; Mokhtar, M.Z. Board independence, ownership and CSR of Malaysian Large Firms. Corp. Ownersh. Control 2011, 8, 417-431. [CrossRef]

94. McWilliams, A.; Siegel, D. Corporate social responsibility: A theory of the firm perspective. Acad. Manag. Rev. 2001, 26, 117-127. [CrossRef]

95. Baron, R.M.; Kenny, D.A. The moderator-mediator variable distinction in social psychological research: Conceptual, strategic, and statistical considerations. J. Personal. Soc. Psychol. 1986, 51, 1173-1182. [CrossRef]

96. Cochran, P.L.; Wood, R.A. Corporate social responsibility and financial performance. Acad. Manag. J. 1984, $27,42-56$. 
97. Tan, J.; Peng, M.W. Organizational slack and firm performance during economic transitions: Two studies from an emerging economy. Strateg. Manag. J. 2003, 24, 1249-1263. [CrossRef]

98. Thompson, J. Organizations in Action; McGraw-Hill: New York, NY, USA, 1967.

99. Grosvold, J.; Brammer, S.; Rayton, B. Board diversity in the United Kingdom and Norway: An exploratory analysis. Bus. Ethics Eur. Rev. 2007, 16, 344-357. [CrossRef]

100. Hafsi, T.; Turgut, G. Boardroom diversity and its effect on social performance: Conceptualization and empirical evidence. J. Bus. Ethics 2013, 112, 463-479. [CrossRef]

101. Bruynseels, L.; Cardinaels, E. The audit committee: Management watchdog or personal friend of the CEO? Account. Rev. 2013, 89, 113-145. [CrossRef]

102. Aguinis, H.; Glavas, A. What we know and don't know about corporate social responsibility: A review and research agenda. J. Manag. 2012, 38, 932-968. [CrossRef]

103. Margolis, J.D.; Walsh, J.P. Misery loves companies: Rethinking social initiatives by business. Adm. Sci. $Q$. 2003, 48, 268-305. [CrossRef]

104. Weber, M. The business case for corporate social responsibility: A company-level measurement approach for CSR. Eur. Manag. J. 2008, 26, 247-261. [CrossRef]

105. Gamerschlag, R.; Möller, K.; Verbeeten, F. Determinants of voluntary CSR disclosure: Empirical evidence from Germany. Rev. Manag. Sci. 2011, 5, 233-262. [CrossRef]

106. Gjølberg, M. Measuring the immeasurable?: Constructing an index of CSR practices and CSR performance in 20 countries. Scand. J. Manag. 2009, 25, 10-22. [CrossRef]

(C) 2018 by the authors. Licensee MDPI, Basel, Switzerland. This article is an open access article distributed under the terms and conditions of the Creative Commons Attribution (CC BY) license (http:/ / creativecommons.org/licenses/by/4.0/). 